\title{
AN INVALID SASKATCHEWAN RECORD OF THE EUROPEAN WIDGEON
}

\section{by Mary Houston and C. Stuart Houston, 863 University Drive, Saskatoon}

The European Widgeon, Mareca penelope, is "recorded rarely but regularly, in North America (on both the Atlanic and Pacific coasts and in the interior ..." After this statement, the 5th A.O.U. Check-list, published in 1957, mentions the localities of, among others, Great Slave Lake, Lake Winnipeg and southern Manitoba. The only authentic record for Alberta is an adult male collected at Valhalla Lake, April 27, 1959 (Salt and Wilk, 1966). Careful observation of male widgeons in spring should result in this species being added to the Saskatchewan list.

It was therefore of great interest to find, while checking the numerous instalments of "Official Canadian Record of Bird-Banding Returns", published in the Canadian FieldNaturalist from May 1924 to March 1932, a record of a banded European Widgeon recovered in Saskatchewan! In Vol. 43, p. 67, we read the following: "EUROPEAN WIDGEON, No. 386, 421, banded by E. W. Ehmann, at Lake Merritt, Oakland, Colifornia, on February 1, 1927, was shot on a slough on the NW $36,1,12$, W3, Saskatchewan, near the International Boundary - reported on October 11, 1927." This location is five miles south and 15 miles east of Masefield, Saskatchewan. This appeared to represent the first valid record of the European Widgeon for Saskatchewan. The May 1929 issue listed another European Widgeon, No. 601,079, banded by Ehmann on December 15, 1927 and shot 18 miles northwest of St. Andrew's Mission, Atikameg, Alberta in May 1928, and this seemed to be the first Alberta record for this species.

One possibility of error still had to be excluded. In Coues' authoritative "Key to North American Birds", published in 1884, two alternative names were listed for the American species, Mareca americana, with "American Widgeon" listed first in preference to "Baldpate." Sportsmen tended to use the former name while ornithologists followed the first four A.O.U. Checklists, beginning in 1886, in using Baldpate. (Only with the 5th A.O.U. Check-list in 1957 did the name officially become American Widgeon). The European species, which occasionally wandered down along the coasts of this continent, was listed by the A.O.U. in 1886 and 1895 simply as "Widgeon" but thereafter as "European Widgeon." Had there been some confusion in Ehmann's use of the term, "widgeon"? This seemed somewhat less likely when we noted that some of Ehmann's other recoveries were listed as "Baldpate."

The next step was to enlist the help of Mrs. Enid K. Austin an Oakland, California bander who once lived near Punnichy, Saskatchewan. She replied that Ehmann was known as a conscientious, careful worker unlikely to make an error in identification. She arranged for Paul Conel and Henry Childs, Sr. to check Ehmann's original banding records which were all present except for the 1927 book which was out on loan! This book was recalled and finally the original record was consulted. Band No. 386,421 on a bird later shot by a Mr. J. A. Underwood in Saskatchewan, was listed as a "female Widgeon." Without a qualifying adjective, at that time this would have referred to the American Widgeon or Baldpate, not to the European species.

Presumably a clerk in the banding office, or someone working for the Canadian Field-Naturalist, not realizing that "Widgeon" and "Baldpate" could be synonymous, and for the American species of Widgeon, must have added the prefix "European." Our common American Widgeon or Baldpate, that breeds in Saskatchewan, usually winter in California and the countries around the Carribean, so this 1927 record is merely an unexciting recovery of an American Widgeon-not a new species for the provincial list after all. 